\title{
PENGGUNAAN MEDIA KARTU MENCARI JODOH DALAM PEMBELAJARAN TEMATIK UNTUK MENINGKATKAN HASIL BELAJAR PESERTA DIDIK SEKOLAH DASAR
}

\author{
Adhita Dwi Handayani \\ Fakultas Agama Islam Universitas Islam Darul 'Ulum Lamongan \\ Jl. Airlangga No. 03 Sukodadi Lamongan \\ Email: adhitadwi1@gmail.com
}

\begin{abstract}
Abstrak
Latar belakang penelitian ini berawal dari guru dalam proses pembelajaran pada waktu menjelaskan materi jarang menggunakan media pembelajaran. Guru lebih dominan menggunakan metode ceramah, cara ini menjadikan peserta didik mengantuk, bercerita dengan teman sebangkunya, dan tidak tertarik dengan materi yang disampaikan. Hal ini mengakibatkan rendahmya hasil belajar peserta didik, maka perlu adanya pemecahan masalah yaitu menggunakan media kartu mencari jodoh. Tujuan peneliti ini untuk mengkaji aktivitas guru dan peserta didik serta hasil belajar peserta didik selama proses pembelajaran tematik dengan menggunakan media kartu Mencari Jodoh pada mata pelajaran Tematik, serta untuk mendeskripsikan respon peserta didik terhadap penggunaan media kartu gambar pada mata pelajaran Tematik. Penelitian ini menggunakan Penelitian Tindakan Kelas. Melalui penggunakan media kartu mencari jodoh diharapkan peserta didik dapat memahami materi mata pelajaran Tematik dengan mudah, cepat dan tepat. Hasil penelitian setelah dipergunakan media kartu Mencari Jodoh adalah peserta didik lebih senang dan antusias dalam proses pembelajaran.
\end{abstract}

Kata kunci : Mata Pelajaran Tematik, Kartu Mencari Jodoh

\begin{abstract}
The background of this research came from the teacher in the learning process at the time rarely explain the material using the teacher explaining instructional media learning materials only with the lecture method alone, so that the way teachers teach students to speak their own making, drowsiness, talked with friends, and students are not interested in learning. This results in lower student learning outcomes, it is necessary to solving the problem is to use the media card image. The researchers' goal was to assess the activity of teachers and students as well as student learning outcomes during the learning process by using a thematic picture card media on thematic subjects are Social Studies and Indonesian, and to describes the students' response to the use of images on the media card thematic subjects. Thematic lessons using picture card media students are expected to understand the thematic subject matter of Social Sciences and
\end{abstract}


the Indonesian easily as using a picture card media more excited and enthusiastic students in the learning process.

Keyword : Thematic Lessons, Media Card Image

\section{A. Pendahuluan}

Satu di antara permasalahan krusial yang masih saja dihadapi lembaga pendidikan negeri ini adalah kurang tersedianya media pembelajaran untuk menunjang pemahaman peserta didik terhadap materi pelajaran. Urgensi ketersediaan media pembelajaran ini seringkali diabaikan oleh para pendidik dengan dalih kurangnya anggaran dan waktu untuk membuatnya. Padahal keberadaan media pembelajaran sangat menentukan efektivitas dan efisiensi kegiatan belajar mengajar. Hal ini karena media pembelajaran berperan sebagai jembatan yang mengantarkan materi-materi yang disampaikan oleh pendidik kepada peserta didik terutama peserta didik di sekolah dasar.

Peserta didik di tingkat sekolah dasar menurut Jean Peaget masih berada pada tahap beripikir operasional konkret. Mereka akan mengalami kesulitan dan membutuhkan waktu lebih lama jika diajak berpikir abstrak. Oleh sebab itu, pembelajaran yang dilakukan harus sebisa mungkin menghadirkan dunia nyata (benda konkret). Melalui benda konkret peserta didik dapat belajar dengan pengalaman yang dilakukan dalam kehidupan sehari-hari.

Berdasarkan hasil obeservasi dan wawancara yang dilakukan pada proses pembelajaran tematik di kelas rendah SDN Sukodadi Lamongan, terlihat peserta didik kurang antusias dalam mengikuti pembelajaran. Banyak peserta didik yang tidak memperhatikan guru saat mengajar, mereka sibuk ngobrol sendiri, tidur-tiduran, serta mengerjakan tugas mata pelajaran yang lain. Hal ini dikarenakan kurangnya penggunaan media yang merangsang minat dalam pembelajaran Tematik. Kemudian diperoleh data tentang kebiasaan dalam proses pembelajaran Tematik di kelas yang dapat digambarkan bahwa banyaknya peserta didik yang memperoleh nilai di bawah Kriteria Ketuntasan Minimal (KKM). Jika dilihat dari 35 orang peserta didik yang ada di kelas, pada pembelajaran Tematik adalah $\geq 70$ anak, dari nilai keseluruhan hanya 
$40 \%$ peserta didik yang bisa mencapai KKM, sedangkan sebanyak $60 \%$ dari mereka masih belum mencapai KKM.

Untuk mengatasi masalah yang dihadapi oleh guru kelas rendah pada saat proses pembelajaran seharusnya menggunakan media pembelajaran yang inovatif. Jenis media pembelajaran yang ditawarkan oleh penulis yaitu media kartu gambar berjodoh. Media kartu gambar berjodoh merupakan media visual yang menghadirkan ilustrasi suatu hal yang hampir menyamai kenyataan dari suatu obyek atau situasi. ${ }^{1}$

Studi mengenai penggunaan pesan visual berupa kartu bergambar dalam hubungan dengan hasil belajar menunjukkan bahwa pesan-pesan visual (bergambar) memberikan pengaruh tinggi terhadap prestasi belajar peserta didik. Pesan visual yang paling sederhana, praktis, mudah dibuat dan banyak diminati peserta didik pada jenjang pendidikan dasar adalah gambar, terlebih lagi gambar berwarna. Para peserta didik pada pendidikan dasar lebih menggemari gambar berwarna daripada hitam putih, dan memilih gambar sederhana daripada yang rumit dan samping itu daya tarik gambar sebagai media pengajaran bergantung pula kepada usia para peserta didik. ${ }^{2}$

Dengan demikian, penggunaan media pembelajaran dapat digunakan untuk meningkatkan hasil belajar peserta didik karena dengan media proses pembelajaran akan lebih mudah dipahami oleh anak didik dan dapat menarik perhatian anak didik untuk selalu berkonsentrasi dalam pembelajaran.

\section{B. Pengertian Media Pembelajaran}

Kata media berasal dari bahasa Latin dan merupakan bentuk jamak dari kata medium yang secara harfiah berarti perantara atau pengantar.Media adalah perantara atau pengantar pesan dari pengirim ke penerima pesan. ${ }^{53}$

Sering kali seorang guru menggunakan berbagai macam media pembelajaran yang bermacam-macam untuk mengajar dan mengetahui berbagai jenis media tersebut, beberapa pendapat membagi media pembelajaran menjadi beberapa jenis. Berdasarkan

\footnotetext{
${ }^{1}$ Azhar Arsyad, Media Pembelajaran (Jakarta: Raja Grafindo Persada, 2009), 78.

2 Nana Sudjana, dkk.,Media Pembelajaran (Bandung:Sinar Baru Algensindo, 2010), 10.

${ }^{3}$ Arief Sadiman, dkk., Media Pendidikan Pengertian, Pengembangan, \& Pemanfaatannya.(Jakarta:PT

Raja Grafindo Persada, 2010), 6
} 
Pollock \& Reigeluth $1992,{ }^{4}$ membagi media pembelajaran sebagai berikut (1) Media berbasis manusia, Contoh: guru, instruktur, tutor, main peran, kegiatan kelompok, dan lain-lain. (2) Media berbasis cetak, Contoh: buku, penuntun, buku latihan (workbook), alat bantu kerja, dan lembar lepas. (3) Media berbasis visual, Contoh: buku, alat bantu kerja, bagan, grafik, peta, gambar, transparansi, slide. (4) Media berbasis audio-visual, Contoh: video, film, program slide-tape, televisi. (5) Media berbasis computer, Contoh: pengajaran dengan bantuan komputer, interaksif video, hypertext.

Fungsi media pembelajaran menurut Sadiman, dkk (1990) menyampaikan fungsi media (media pendidikan) secara umum, adalah sebagai berikut: (a) Memperjelas penyajian pesan agar tidak terlalu bersifat visual; (b) Mengatasi keterbatasan ruang, waktu, dan daya indera, misal objek yang terlalu besar untuk dibawa ke kelas dapat diganti dengan gambar, slide, dab sebagainya. Peristiwa yang terjadi di masa lalu bisa ditampilkan lagi lewat film, video, fota atau film bingkai; (c) Meningkatkan kegairahan belajar, memungkinkan siswa belajar sendiri berdasarkan minat dan kemampuannya, dan mengatasi sikap pasif siswa; (d) Memberikan rangsangan yang sama, dapat menyamakan pengalaman dan persepsi siswa terhadap isi pelajaran. ${ }^{5}$

Berdasarkan taksonomi Rudy Betz media kartu gambar termasuk media gambar. Media berasal dari dari bahasa Latin dan merupakan bentuk jamak dari kata medium yang secara harfiah berarti perantara atau pengantar ${ }^{7}{ }^{6}$ Media adalah perantara atau pengantar pesan dari pengirim ke penerima pesan.Asosiasi Teknologi dan Komunikasi Pendidikan(Association of Education and Communication Technology/AECT) di Amerika membatasi media sebagai segala bentuk dan saluran yang digunakan orang untuk menyampaikan pesan atau informasi. Dari berbagai pendapat yang sudah dijelaskan diatas dapat diartikan bahwa pengertian media secara umum adalah segala sesuatu yang dapat digunakan untuk menyalurkan informasi dari sumber informasi kepada siswa sehingga tercipta proses belajar mengajar yang efektif dan efesien.

\footnotetext{
${ }^{4}$ AzharArsyad, Media Pembelajaran..., 36.

${ }^{5}$ Ibid, 23.

${ }^{6}$ Arief Sadiman dkk., Media Pendidikan Pengertian, Pengembangan, \& Pemanfaatannya.Jakarta:PT Raja Grafindo Persada, 2010), 6-7.
} 


\section{Media Pembelajaran Kartu Berjodoh}

Terdapat cara - cara dalam membuat media kartu jodoh, antara lain: (a) Siapkan kertas duplek yang tebal yang berfungsi untuk menempelkan gambar - gambar. Duplek ini di potong dengan ukuran kurang lebih 10x15cm sehingga berbentuk persegi panjang menyerupai kartu, (b) Duplek tersebut diberikan tanda dengan pensil atau spidol dan menggunakan penggaris untuk menentukan ukurannya, (c) Potong-potongan duplek tersebut dapat menggunakan gunting atau pisau kater hingga tepat berukuran 10x15cm. Buatlah kartu-kartu tersebut sejumlah gambar yang akan ditempelkan atau sejumlah siswa dan materi, (d) Duplek ini dapat dibungkus dengan kertas kado ataupun kertas HVS yang berwarna supaya warnanya lebih menarik perhatian siswa. Jika duplek sebagai kartu ini tidak dibuat sendiri, dapat juga membeli kartu-kartu seperti halnya kartu remi, kartu domino yang sudah jadi melainkan ukurannya yang lebih kecil sedikit, (e) Siapkan gambar - gambar yang akan ditempelkan pada duplek sebagai kartu tersebut. Untuk menempelkannya, maka gambar tersebut harus diberi lem perekat. Gambar - gambar tersebut dapat diambil dari majalah, koran, tabloid atau gambar yang dibeli dari toko. Banyaknya gambar yang ditempelkan sesuai dengan kebutuhan dan keluasan materi yang disajikan. Gambar tersebut harus saling berhubungan contohnya saja materi tentang pancasila maka menyediakan gambar antara bunyi sila ke satu dan lambanganya jadi nanti bisa di dijodohkan antara pertanyaan dan jawabannya.

Beberapa cara penggunaan media kartu gambar adalah sebagai berikut: (a) Siapkan kartu yang sudah ditempeli gambar dari pertanyan dan jawabannya tersebut, (b) Setiap siswa yang berdiri melingkar diberi kesempatan untuk mengambil kartu dengan berbagai macam warna karena posisi kartu gambarnya terbalik, (c) Setiap siswa harus mencari jodoh dari jawaban atau pasangan kartu gambar yang dibawahnya sesuai dengan aba-aba atau soal yang diberikan oleh gurunya, (c) Setelah bertemu dengan jodoh kartu yang dibawahnya, maka setiap siswa harus berkelompok tidak boleh terpisah dan menentukan tempat yang dipilihnya untuk tempat duduknya, (d) Kartu gambar yang berjodoh dapat berjumlah 2-3 kartu, (e) Setelah batas waktu yang ditentukan habis (misalnya 15 menit), guru meniupkan peluit sebagai tanda waktu penggunaan media kartu jodoh habis, (f) Kartu jodoh yang sudah dijodohkan 
didiskusikan bersama sekelompoknya tersebut kartutersebut apakah sudah berjodoh ataupun belum berjodoh, (g) Apabila yang benar dan mendapatkan waktu tercepat, maka kelompok tersebutlah yang mendapatkan reword, (h) Ulangi penggunaan media kartu jodoh ini sekali lagi atau lebih agar semua siswa memahami materi yang sedang dipelajari, (i) Rayakan proses pembelajaran menggunakan media kartu ini, dengan cara berteriak bersama-sama supaya tampak bergairah dan semangat, (j) Guru dapat memberikan semangat dengan cara teriak ataupun bernyanyi.

\section{E. Pembelajaran Tematik}

Pembelajaran tematik dimaknai sebagai pembelajaran yang dirancang berdasarkan tema-tema tertentu. Dalam pembahasannya tema itu ditinjau dari berbagai mata pelajaran. Pembelajaran tematik menyediakan keluasan dan kedalaman implementasi kurikulum, menawarkan kesempatan yang sangat banyak pada siswa untuk memunculkan dinamika dalam pendidikan.

Senada dengan pendapat diatas menurut, pembelajaran terpadu adalah pembelajaran yang diawali dengan suatu pokok bahasan atau tema tertentu yang dikaitkan dengan pokok bahasan lain, konsep tertentu dikaitkan dengan konsep lain, yang dilakukan secara spontan atau direncanakan, baik dalam satu bidang studi atau lebih, dan dengan beragam pengalaman belajar anak, maka pembelajaran menjadi lebih bermakna. $^{7}$

Pembelajaran tematik sebagai model pembelajaran memiliki arti penting dalam membangun kompetensi peserta didik, antara lain: Pertama, pembelajaran tematik lebih menekankan pada keterlibatan siswa dalam proses belajar secara aktif dalam proses pembelajaran, sehingga siswa dapat memperoleh pengalaman langsung dan terlatih untuk dapat menemukan sendiri berbagai pengetahuan yang dipelajarinya. Melalui pengalaman langsung siswa akan memahami konsep-konsep yang mereka pelajari dan menghubungkannya dengan konsep lain yang telah dipahaminya. Teori pembelajaran ini dimotori para tokoh Psikologi Gestalt, termasuk Piaget yang menekankan bahwa pembelajaran haruslah bermakna dan berorientasi pada kebutuhan dan perkembangan

\footnotetext{
${ }^{7}$ Ibid, 6
} 
anak. Kedua, pembelajaran tematik lebih menekankan pada penerapan konsep belajar sambil melakukan sesuatu (learning by doing). ${ }^{8}$

Pembelajaran tematik dalam kenyataannya memiliki beberapa kelebihan seperti pembelajaran terpadu. Menurut Dapartemen Pendidikan dan Kebudayaan pembelajaran tepadu memiliki kelebihan sebagai berikut: (a) Pengalaman dan kegiatan belajar anak relevan dengan tingkat perkembangannya, (b) Kegiatan yang dipilih sesui dengan minat dan kebutuhan anak, (c) Kegiatan belajar bermakna bagi anak, sehingga hasilnya dapat bertahan lama, (d) Keterampilan berpikir anak berkembang dalam proses pembelajaran terpadu, (e) Kegiatan belajar mengajar bersifat pragmatis sesuai lingkungan anak, (f) Keterampilan sosial anak berkembang dalam proses pembelajaran terpadu. Keterampilan sosial ini antara lain adalah: kerja sama, komunikasi, dan mendengarkan pendapat orang lain. ${ }^{9}$

Selain kelebihan yang dimiliki, pembelajaran tematik juga memiliki keterbatasan, terutama dalam pelaksanaannya, yaitu pada perencanaan dari pelaksanaan evaluasi yang lebih banyak menuntut guru untuk melakukan evaluasi proses, dan tidak hanya evaluasi dampak pembelajaran langsung saja. ${ }^{10}$

Sintaks pembelajaran tematik pada dasarnya mengikuti langkah-langkah (sintaks) pembelaran terpadu. Secara umum sintaks tersebut mengikuti tahap-tahap yang dilalui dalam setiap model pembelajaran yang meliputi 3 tahap yaitu tahap perencanaan, tahap pelaksanaan, dan tahap evaluasi. Berkaitan dengan itu maka sintaks model pembelajaran tematik dapat direduksi dari berbagai model pembelajaran seperti model pembelajaran langsung (direct intruction), model pembelajaran kooperatif (cooperativ learning), maupun pembelajaran berdasarkan masalah(problem based instructions). ${ }^{11}$

Berdasarkan ketentuan tersebut, maka sintaks pembelajaran terpadu dapat bersifat luwes dan fleksibel. Artinya, bahwa sintaks dalam pembelajaran tematik dapat diakomodasi dari berbagai model pembelajaran yang dikenal dengan istilah setting ataumerekonstruksi. Langkah-langkah (sintaks) pembelajaran terpadu secara khusus

\footnotetext{
${ }^{8}$ Ibid, 86

${ }^{9} \mathrm{Ibid}, 88$

${ }^{10}$ Trianto, Mengembangkan Model Pembelajaran Tematik (Jakarta: Prestasi Pustakaraya, 2010), 89.

${ }^{11}$ Ibid., 95 .
} 
dapat dibuat tersendiri berupa langkah-langkah baru dengan ada sedikit perbedaan yakni sebagai berikut: (a) Pertama, Tahap Perencanaan. Pada tahap ini hal-hal yang dilakukan oleh guru antara lain (1) Menentukan kompetensi dasar, (2) Menentukan indikator dan hasil belajar, (b) Kedua, Tahap Pelaksanaan, yang meliputi sub-tahap: Proses pembelajaran oleh guru.

\section{F. Hasil Belajar}

Hasil belajar adalah kemampuan yang diperoleh anak setelah melalui kegiatan belajar. Belajar itu sendiri merupakan suatu proses dari seseorang yang berusaha untuk memperoleh suatu bentuk perubahan perilaku yang relatif menetap. Hasil belajar merupakan keluaran (output) dari suatu sistem pemrosesan masukan (input). ${ }^{12}$

Berpendapat bahwa hasil belajar yang dicapai siswa dipengaruhi oleh lima faktor yaitu: (a) Bakat pelajar. (b) Waktu yang tersedia untuk belajar, (c) Waktu yang diperlukan siswa untuk menjelaskan pelajaran, (d) Kualitas pengajaran, (e) Kemampuan individu. $^{13}$

Berdasarkan pendapat dapat disimpulkan bahwa pada dasarnya faktor-faktor yang mempengaruhi prestasi belajar siswa dapat dibedakan menjadi dua faktor, yaitu faktor yang berasal dari dalam diri individu dan faktor yang berasal dari luar diri individu. Kedua faktor ini mempunyai hubungan berbanding lurus dengan hasil belajar siswa, artinya makin tinggi kemampuan siswa dan kualitas belajar makin tinggi pula hasil belajar siswa.

\section{G. Metode Penelitian}

Berdasarkan permasalahan yang ada maka peneliti menggunakan Penelitian Tindakan Kelas yang bertujuan untuk dapat mengetahui keberhasilan hasil belajar siswa dengan menggunakan media kartu jodoh. Penelitian Tindakan Kelas menurut Arikunto adalah Penelitian menunjukkan pada suatu kegiatan mencermati suatu obyek,menggunakan aturan metodologi tertentu untuk memperoleh data atau informasi yang bermanfaat untuk meningkatkan mutu dari suatu hal yang menarik minat dan

\footnotetext{
${ }^{12}$ Nana Sudjana.Dasar-Dasar Proses Belajar Mengajar (Bandung:Sinar Baru Algensindo, 2011), 40. ${ }^{20}$ Ibid., 40..
} 
penting bagi penelitian. Tindakan adalah sesuatu gerak kegiatan yang sengaja dilakukan dengan tujuan tertentu, yang dalam penelitian berbentuk siklus kegiatan untuk siswa. Kelas adalah sekelompok siswa yang dalam waktu yang sama menerima pelajaran sama dari seorang guru. Dalam hal ini tidak terikat pada pengertian ruang kelas, tetapi dalam pengertian yang lebih spesifik.

Prosedur PTK (Penelitian Tindakan Kelas) dilaksanakan melalui tiga tahap (komponen) utama, yaitu perencanaan, tindakan, dan pengamatan, serta refleksi. Ketiga komponen utama yang saling berkaitan tersebut sering diistilahkan dengan siklus (satu siklus).Setiap siklus dilakukan dua kali pertemuan.

Pada tahap perencanaan tindakan kegiatan pembelajaran siklus I pertemuan 1 dilaksanakan pada tanggal 07 Agustus 2017 di ruang kelas III SDN Sukodadi Lamongan. Kegiatan pada tahap ini adalah: (1) Menentukan standart kompetensi dan kompetensi dasar. (2) Menentukan jadwal penelitian siklus 1 yaitu tanggal 07 Agustus 2017dengan alokasi waktu 2x pertemuan adalah 4x35menit. (3) Membuat silabus berdasarkan Standart Kompetensi dan Kompetensi Dasar yang telah ditentukan. (4) Membuat rencana pelaksanaan pembelajaran (RPP) tentang materi yang sudah direncanakan. (5) Mempersiapkan media yang digunakan pada pembelajaran.Media yang digunakan dalam penelitian ini adalah media kartu gambar. Media pembelajaran ini digunakan untuk memudahkan guru dalam menjelaskan materi. (6) Membuat instrumen yang digunakan peneliti yaitu lembar observasi aktivitas guru dan lembar observasi aktivitas siswa dan angket respon siswa. (7) Membuat alat evaluasi yang sesuai dengan tujuan pembelajaran. (8) Menyusun Instrumen Penelitian.

Tahap pelaksanaan dilakukan pada saat proses pembelajaran sesuai dengan rencana pelaksanaan pembelajaran (RPP) yang telah disusun. Siklus I dilakukan dua kali pertemuan. Pertemuan 1 dan pertemuan 2 dengan alokasi waktu 4 x 35 menit.

Pada tahap pengamatan diamati oleh 2 pengamat, yakni: guru kelas dan teman sejawat. Kedua pengamat tersebut akan mengamati aktivitas gurudan siswa dalam proses pembelajaran berlangsung dengan menggunakan lembar instrumen yang sudah disiapkan. Pada tahapan Refleksi dimaksudkan untuk mengaji secara menyeluruh tindakan yang telah dilakukan, berdasarkan data yang telah terkumpul, kemudian 
dilakukan evaluasi guna menyempurnakan tindakan berikutnya. (a) mengkaji hasil observasi yang telah dilakukan. (b) menganalisis hasil belajar siswa. (c) menganalisis dan mendiskusikan hasil pengamatan. Selanjutnya membuat suatu refleksi mana yang perlu dipertahankan dan mana yang perlu diperbaiki untuk siklus selanjutnya.

Instrumen penelitian yang digunakan untuk memperoleh data yang diperlukan, yaitu: (a) lembar pengamatan aktivitas guru. Instrumen penelitian ini digunakan untuk mengamati aktivitas guru selama proses pembelajaran menulis deskripsi berlangsung. Lembar observasi diisi oleh pengamat; (b) lembar pengamatan aktivitas siswa. Instrumen penelitian ini digunakan untuk mengamati aktivitas siswa selama proses pembelajaran dengan cara menulis deskripsi selama pembelajaran berlangsung. Lembar observasi diisi oleh pengamat; (c) hasil belajar siswa dengan menggunakan media kartu jodoh pada pembelajaran tematik berupa evaluasi LKS dan Lembar Penilaian (LP).

Analisis data yang akan digunakan dalam penelitian ini adalah analisis data kualitatif dan kuantitatif. Berikut ini akan dijelaskan mengenai analisis data kualitatif dan kuantitatif. Analisis data kualitatif adalah Data yang didapatkan terdiri atas hasil observasi mengenai aktivitas guru dan siswa pada saat pembelajaran berlangsung yang berupa lembar observasi.

Hasil observasi dalam penelitian ini berupa hasil pengamatan aktivitas siswa maupun guru dalam proses belajar mengajar berlangsung. Data tersebut diolah untuk memperoleh simpulan dan dipilih berdasarkan kategori pengamatan sehingga diperoleh gambaran aktivitas siswa dan guru dalam proses pembelajaran dengan menerapkan proses pembelajaran tematik dengan menggunakan media kartu gambaran.

Sedangkan data penelitian kuantitatif adalah data yang didapatkan atas hasil tes belajar siswa yang berupa peningkatan hasil belajar siswa pada aspek kognitif, afektif, dan psikomotor dalam pembelajaran tematik dengan menggunakan media kartu jodoh.

Indikator keberhasilan penelitian ini sebagai berikut: (a) Aktivitas guru dalam kegiatan pembelajaran mencapai keberhasilan lebih atau sama dengan 80\%. (b) Aktivitas siswa dalam kegiatan pembelajaran mencapai keberhasilan lebih atau sama dengan $80 \%$. (c) Siswa dikatakan tuntas belajar secara individual jika memperoleh nilai apabila $\geq 70$ dan dikatakan tuntas secara klasikal jika 80\% siswa mencapai $\geq 70$. 


\section{H. Hasil Dan Pembahasan}

Pada siklus I tahap pelaksanaan dilakukan pada saat kegiatan pembelajaran berlangsung. Kegiatan pembelajaran ini dilaksanakan sesuai RPP yang telah disusun dengan alokasi waktu setiap pertemuan 4x35 menit.

\section{Pertemuan Pertama}

Kegiatan pembelajaran tersebut dapat dideskripsikan sebagai berikut.Pada kegiatan awal, apersepsi dilakukan dengan cara guru mengajak bernyanyi bersama dengan judul lagu bapak polisi dan naik delman. Menanyakan kepada anak-anak apakah anak-anak pernah melihat bapak polisi dan menghasilkan apakah pekerjaan tersebut. Kegiatan apresepsi dilakukan guru dengan baik. Ketika guru menyampaikan materi tentang jenis-jenis pekerjaan, siswa sangat senang sekali. Karena pada saat menyampaikan materi tersebut guru menggunakan media kartu jodoh. Sehingga membuat antusias siswa untuk semangat belajar. Karena media kartu jodoh penggunaannya sangatlah unik dan berbeda, serta pembelajaran tersebut mengajak siswa untuk bermain sambil belajar.

Kegiatan yang dilakukan oleh guru pada inti pembelajaran yaitu guru menjelaskan tentang jenis-jenis pekerjakan dengan menggunakan media kartu jodoh. Guru dan siswa saling bertanya jawab. Sebagian siswa yang belum paham tetang penjelasan guru maka siswa tersebut bertanya. Dan guru juga bertanya kepada siswa uuntuk mengecek konsentrasi siswa. Seluruh siswa sangat senang sekali karena pembelajaran tersebut menggunakan kartu jodoh sebagai medianya.

Kegiatan selanjutnya adalah guru membentuk kelompok, setiap kelompok terdapat 4 atau 5 dalam anggotanya. Kelompok dibentuk sesuai dengan tempat duduk yang sudah berkelompok tetapi tetap dibagi lagi, karena tempat duduk tersebut kelompoknya terlalu banyak. Setiap kelompok memberi nama kelompoknya dengan nama jenis-jenis pekerjaan. Kemudian guru membagikan LKS untuk dikerjakan bersama dalam satu kelompok. Guru memantau aktivitas kelompok tersebut. Setelah selesai perwakilan diminta untuk mempresentasikan hasil diskusinya tersebut. Setiap 
kelompok sangat senang sekali karena dalam penggunaan kartu jodoh dengan cara bermain. Pada saat presentasi, kelompok lain menanggapi kelompok yang sedang memperesentasikan hasilnya. Setelah itu guru memberikan lembar penilaian kepada siswa.

Kegiatan selanjutnya pada akhir pembelajaran guru bersama siswa bersamasama menyimpulkan pembelajaran kemudian guru memberikan reword kepada kelompok yang paling banyak memiliki nilai terbaik dan siswa yang aktif dalam pembelajaran. pada saat itu. Guru memberikan tugas lanjutan berupa tugas rumah. Guru menutup pembelajaran dan tidak lupa memberikan pesan moral kepada siswa.

\section{Pertemuan Kedua}

Kegiatan pembelajaran tersebut dapat dideskripsikan sebagai berikut.Pelaksanaan pembelajaran meliputi kegiatan awal, kegiatan inti, kegiatan akhir. Kegiatan pada awal pembelajaran adalah apersepsi dilakukan dengan cara guru mengajak bernyanyi bersama dengan judul lagu bapak polisi dan naik delman seperti pada pertemuan sebelumnya. Dan bertanya kepada siswa siapa diantara kalian yang bisa menyebutkan 3 contoh pekerjaan penghasil barang dan jasa. Kegiatan apresepsi dilakukan guru dengan baik. Ketika guru menyampaikan materi tentang jenis-jenis pekerjaan, siswa sangat senang sekali. Karena pada saat menyampaikan materi tersebut guru menggunakan media kartu jodoh. Sehingga membuat antusias siswa untuk semangat belajar. Karena media kartu jodoh penggunaannya sangatlah unik dan berbeda, serta pembelajaran tersebut mengajak siswa untuk bermain sambil belajar.

Kegiatan yang dilakukan oleh guru pada inti pembelajaran yaitu guru menjelaskan tentang jenis-jenis pekerjakan dengan menggunakan media kartu jodoh. Guru dan siswa saling bertanya jawab. Sebagian siswa yang belum paham tetang penjelasan guru maka siswa tersebut bertanya. Dan guru juga mengadakan pertanyaan kepada siswa untuk mengecek konsentrasi siswa. Seluruh siswa sangat senang sekali karena pembelajaran tersebut menggunakan kartu jodoh sebagai medianya. 
Kegiatan selanjutnya adalah guru membentuk kelompok, setiap kelompok terdapat 4 atau 5 dalam anggotanya. Kelompok dibentuk sesuai dengan tempat duduk yang sudah berkelompok tetapi tetap dibagi lagi, karena tempat duduk tersebut kelompoknya terlalu banyak. Setiap kelompok memberi nama kelompoknya dengan nama jenis-jenis pekerjaan. Kemudian guru membagikan LKS untuk dikerjakan bersama dalam satu kelompok. Guru memantau aktivitas kelompok tersebut. Setelah selesai perwakilan diminta untuk mempresentasikan hasil diskusinya tersebut. Setiap kelompok sangat senang sekali karena dalam penggunaan kartu gambar dengan cara bermain. Pada saat presentasi, kelompok lain menanggapi kelompok yang sedang memperesentasikan hasilnya. Setelah itu guru memberikan lembar penilaian kepada siswa.

Kegiatan selanjutnya pada akhir pembelajaran guru bersama siswa bersamasama menyimpulkan pembelajaran kemudian guru memberikan reword kepada kelompok yang paling banyak memiliki nilai terbaik dan siswa yang aktif dalam pembelajaran. pada saat itu. Guru memberikan tugas lanjutan berupa tugas rumah. Guru menutup pembelajaran dan tidak lupa memberikan pesan moral kepada siswa.

Tahap refleksi dilakukan untuk mengevaluasi tindakan yang telah dilakukan guna memperbaiki tindakan berikutnya. Setelah melaksanakan kegiatan pembelajaran tematik menggunakan media kartu jodoh pada siklus I, guru bersama pengamat melakukan refleksi terhadap pelaksanaan kegiatan pembelajaran yang telah dilakukan. Berdasarkan hasil refleksi, aktivitas guru pada siklus I yang perlu diperbaiki, yaitu pada saat (1) Memberi apersepsi, (2) Menyampaikan tujuan pembelajaran, (3)Membentuk kelompok, meminta untuk mengerjakan lembar LKS dan membimbing siswa dalam kelompok, (4) Mengecek laporan hasil kerja siswa dalam kelompok, (5) Memberikan lembar penilaian, (6) Menutup pelajaran, (7) Pengolahan waktu, (8) Antusias guru. Disamping itu aspek yang cukup dan belum mencapai ketuntasan minimal adalah meminta keaktifan siswa dalam pelaksanaan media kartu jodoh. 
Tahap pelaksanaan pada siklus II dilakukan pada saatkegiatan pembelajaran berlangsung. Kegiatan pembelajaran ini dilaksanakan sesuai RPP yang telah disusun dengan alokasi waktu setiap pertemuan 2x35 menit.

\section{Pertemuan Pertama}

Kegiatan pembelajaran tersebut dapat dideskripsikan sebagai berikut.Kegiatan pada awal pembelajaran adalah apersepsi dilakukan dengan cara guru bertanya kepada siswa, siapa diantara kalian yang mengetahui pekerjaan orang tua kalian, pekerjaan tersebut menghasilkan apa. Kegiatan apresepsi dilakukan guru dengan baik. Ketika guru menyampaikan materi tentang pekerjaan orangtua siswa, siswa sangat senang sekali dan sangat antusias. Karena pada saat menyampaikan materi tersebut guru menggunakan media. Sehingga membuat antusias siswa untuk semangat belajar. Karena media kartu jodoh penggunaannya sangatlah unik dan berbeda yaitu dengan cara mencari jodohnya atau pasangannya antara gambar pekerjaan dengan yang dihasilkan oleh pekerjaan tersebut, sehingga pembelajaran tersebut mengajak siswa untuk bermain sambil belajar.

Kegiatan yang dilakukan oleh guru pada inti pembelajaran yaitu guru menjelaskan tentang pekerjakan orang tua siswa dengan menggunakan media kartu jodoh. Guru dan siswa saling bertanya jawab. Sebagian siswa yang belum paham tetang penjelasan guru maka siswa tersebut bertanya. Dan guru juga menberikan pertanyaan kepada siswa untuk mengecek konsentrasi siswa. Seluruh siswa sangat senang sekali karena pembelajaran tersebut menggunakan kartu jodoh sebagai medianya.

Kegiatan selanjutnya adalah guru membentuk kelompok, setiap kelompok terdapat 4 atau 5 dalam anggotanya. Kelompok dibentuk sesuai dengan tempat duduk yang sudah berkelompok tetapi tetap dibagi lagi, karena tempat duduk tersebut kelompoknya terlalu banyak. Setiap kelompok memberi nama kelompoknya dengan nama jenis-jenis pekerjaan. Kemudian guru membagikan LKS untuk dikerjakan bersama dalam satu kelompok. Guru memantau aktivitas kelompok tersebut. Setelah selesai perwakilan diminta untuk mempresentasikan hasil diskusinya tersebut. Setiap kelompok sangat senang sekali karena dalam penggunaan kartu gambar dengan cara 
bermain yaitu dijodohkan. Pada saat presentasi, kelompok lain menanggapi kelompok yang sedang memperesentasikan hasilnya. Setelah itu guru memberikan lembar penilaian kepada siswa secara individu.

Kegiatan selanjutnya pada akhir pembelajaran guru memberikan reward kepada kelompok yang paling benyak memiliki nilai terbaik dan siswa yang aktif dalam pembelajaran. Kemudian guru bersama siswa bersama-sama menyimpulkan pembelajaran pada saat itu. Guru memberikan tugas lanjutan berupa tugas rumah. Guru menutup pembelajaran dan tidak lupa memberikan pesan moral kepada siswa.

\section{Pertemuan Kedua}

Kegiatan pembelajaran tersebut dapat dideskripsikan sebagai berikut.Kegiatan pada awal pembelajaran adalah apersepsi dilakukan dengan cara guru bertanya kepada siswa, siapa diantara kalian yang mengetahui pekerjaan seseorang yang ada disekeliling kita, coba sebutkan. Kegiatan apersepsi dilakukan guru dengan baik. Ketika guru menyampaikan materi tentang pekerjaan orang tua siswa, siswa sangat senang sekali dan sangat antusias. Karena pada saat menyampaikan materi tersebut guru menggunakan media kartu jodoh. Sehingga membuat antusias siswa untuk semangat belajar. Karena media kartu gambar penggunaannya sangatlah unik dan berbeda yaitu dengan cara mencari jodohnya atau pasangannya antara gambar pekerjaan dengan yang dihasilkan oleh pekerjaan tersebut, sehingga pembelajaran tersebut mengajak siswa untuk bermain sambil belajar.

Kegiatan yang dilakukan oleh guru pada inti pembelajaran yaitu guru menjelaskan tentang pekerjakan yang ada disekeliling kita dengan menggunakan media kartu gambar. Guru dan siswa saling bertanya jawab. Sebagian siswa yang belum paham tetang penjelasan guru maka siswa tersebut bertanya. Dan guru juga mengadakan pertanyaan kepada siswa untuk mengecek konsentrasi siswa. Seluruh siswa sangat senang sekali karena pembelajaran tersebut menggunakan kartu jodoh sebagai medianya.

Kegiatan selanjutnya adalah guru membentuk kelompok, setiap kelompok terdapat 4 atau 5 dalam anggotanya. Kelompok dibentuk sesuai dengan tempat duduk yang sudah berkelompok tetapi tetap dibagi lagi, karena tempat duduk tersebut 
kelompoknya terlalu banyak. Setiap kelompok memberi nama kelompoknya dengan nama jenis-jenis pekerjaan. Kemudian guru membagikan LKS untuk dikerjakan bersama dalam satu kelompok. Guru memantau aktivitas kelompok tersebut. Setelah selesai perwakilan diminta untuk mempresentasikan hasil diskusinya tersebut. Setiap kelompok sangat senang sekali karena dalam penggunaan kartu gambar dengan cara bermain yaitu dijodohkan. Pada saat presentasi, kelompok lain menanggapi kelompok yang sedang mempresentasikan hasilnya. Setelah itu guru memberikan lembar penilaian kepada siswa secara individu.

Kegiatan selanjutnya pada akhir pembelajaran guru memberikan reword kepada kelompok yang paling banyak memiliki nilai terbaik dan siswa yang aktif dalam pembelajaran. Kemudian guru bersama siswa bersama-sama menyimpulkan pembelajaran pada saat itu. Guru memberikan tugas lanjutan berupa tugas rumah. Guru menutup pembelajaran dan tidak lupa memberikan pesan moral kepada siswa.

Setelah melaksanakan kegiatan pembelajaran tematik dengan menggunakan media kartu jodoh pada siklus II, guru bersama pengamat mengevaluasi pelaksanaan kegiatan pembelajaran yang telah dilakukam. Guru sudah merefleksi proses pembelajaran pada siklus I, sehingga pada siklus II telah tercapai hasil yang diharapkan sesuai dengan nilai ketercapaian dari aktivitas guru dan hasil belajar siswa mengalami peningkatan. Oleh karena itu, pembelajaran pada siklus II berjalan dengan menyenangkan dan antusias dalam mengikuti proses pembelajaran.

Kegiatan pembelajaran yang dilakukan guru pada siklus II sudah baik. Oleh karena itu, kegiatan pembelajaran ini hendaknya dapat dipertahankan agar proses belajar mengajar lebih optimal. Berikut ini adalah tabel aktivitas guru, aktivitas siswa, dan hasil belajar siswa disajikan sebagai berikut:

Tabel 1

Data Hasil Aktivitas Guru

\begin{tabular}{|c|c|c|c|}
\hline \multicolumn{2}{|c|}{ Siklus I } & \multicolumn{2}{c|}{ Siklus II } \\
\hline $\begin{array}{c}\text { Pertemuan } \\
1\end{array}$ & $\begin{array}{c}\text { Pertemuan } \\
2\end{array}$ & $\begin{array}{c}\text { Pertemuan } \\
1\end{array}$ & Pertemuan \\
2 \\
\hline $75 \%$ & $77,3 \%$ & $85 \%$ & $92,9 \%$ \\
\hline
\end{tabular}


Tabel 2

Hasil Aktivitas Siswa Siklus I dan Siklus II

\begin{tabular}{|c|c|c|c|}
\hline \multicolumn{2}{|c|}{ Sikulus I } & \multicolumn{2}{c|}{ Siklus II } \\
\hline Pertemuan 1 & Pertemuan 2 & Pertemuan 1 & Pertemuan 2 \\
\hline $73,4 \%$ & $77,7 \%$ & $87,5 \%$ & $91,6 \%$ \\
\hline
\end{tabular}

Tabel 3

Hasil Belajar Siswa Siklus I dan Siklus II

\begin{tabular}{|c|c|}
\hline Siklus I & Siklus II \\
\hline $69,8 \%$ & $\mathbf{8 6 , 8 \%}$ \\
\hline
\end{tabular}

Aktivitas guru sangat memegang peran penting dalam proses pembelajaran, sehingga dapat meningkatkan kualitas dalam pembelajaran. Kemampuan guru dalam kegiatan pembelajaran berpengaruh terhadap keberhasilan pembelajaran di kelas. Aktivitas guru dalam menggunakan media kartu gambar pada siklus I pertemuan 1 sebesar $75 \%$, ini menunjukkan bahwa aktivitas guru selama proses pembelajaran sudah baik, namun belum mencapai kriteria keberhasilan lebih dari atau sama dengan $80 \%$. Setelah adanya perbaikan pada siklus I pertemuan 2 diperoleh presentase keberhasilan mencapai 77,3\%, ini menunjukkan bahwa aktivitas guru selama proses pembelajaran sudah baik, namun belum mencapai kriteria keberhasilan lebih dari atau sama dengan $80 \%$. Tetapi sudah mengalami kenaikan 3,1\% dari siklus I pertemuan 1 .

Kegiatan siklus II pertemuan 1 diperoleh presentase keberhasilan mencapai $85 \%$. Hal ini menunjukkan adanya kenaikan yang cukup besar yakni 7,7\% dari 77,3\% menjadi $85 \%$. Hal ini menunjukkan bahwa aktivitas guru sudah mencapai ketuntasan minimal yang ditetapkan yaitu $80 \%$. Kegiatan siklus II pertemuan 2 diperoleh presentase keberhasilan mencapai 92,9\%. Hal ini menunjukkan adanya kenaikan yakni $7.9 \%$ dari $85 \%$ menjadi 92,9\%. Hal ini menunjukkan bahwa aktivitas guru sudah mencapai ketuntasan minimal yang ditetapkan yaitu $80 \%$. 
Aktivitas siswa dalam kegiatan pembelajaran dengan menggunakan media kartu jodoh pada siklus I pertemuan 1 menunjukkan 73,4\%. Ini menunjukkan bahwa aktivitas siswa pada siklus I pertemuan 1 masih belum mencapai kriteria yang ditetapkan yaitu $80 \%$. Aktivitas siswa pada siklus I pertemuan 2 dalam diagram 4.2 diperoleh presentase rata-rata $77,7 \%$. Ini menunjukkan bahwa aktivitas siswa pada siklus I pertemuan 2 masih belum mencapai kriteria yang ditetapkan yaitu $80 \%$. Tetapi sudah meningkat $4.3 \%$ dari siklus I pertemuan $173,4 \%$ kemudian siklus I pertemuan 2 menjadi $77,7 \%$.

Aktivitas siswa pada siklus II pertemuan 1 dalam diagram 4.2 diperoleh presentase rata-rata $87,5 \%$. Ini menunjukkan bahwa aktivitas siswa pada siklus II pertemuan 1 meningkat 9,8 dari siklus I pertemuan 2 77,7\% dan siklus II pertemuan $187,5 \%$. Hal ini menunjukkan bahwa aktivitas siswa sudah mencapai ketuntasan minimal yang ditetapkan yaitu $80 \%$. Aktivitas siswa pada siklus II pertemuan 2 dalam diagram 4.2 diperoleh presentase rata-rata 91,6\%. Ini menunjukkan bahwa aktivitas siswa pada siklus II pertemuan 2 meningkat 4,1 dari siklus II pertemuan 1 . Hal ini menunjukkan bahwa aktivitas siswa sudah mencapai ketuntasan minimal yang ditetapkan yaitu $80 \%$.

Hasil belajar siswa pada siklus I dengan jumlah siswa yang mengikut adalah 37 siswa, sedangkan kriteria ketuntasan belajar adalah 70. Dari hasil tersebut terlihat 12 siswa belum mencapai kriteria ketuntasan minimal dan 25 siswa sudah mencapai atau melampui kriteria ketuntasan minimal belajar. Sedangkan rata-rata siswa hanya 69,8 . Seharusnya $80 \%$ siswa harus mencapai atau melampui kriteria ketuntasan minimal belajar.

Hasil belajar siswa pada siklus II dengan jumlah siswa yang mengikut adalah 37 siswa, sudah meningkat dibandingkan dari siklus I , dari 69,8\% menjadi $86,8 \%$ sudah mencapai atau melampui kriteria ketuntasan belajar. Dari hasil tersebut terlihat 3 siswa belum mencapai kriteria ketuntasan minimal dan 34 siswa sudah mencapai atau melampui kriteria ketuntasan minimal belajar Sedangkan nilai rata-rata kelas secara klasikal adalah $86,8 \%$. Hal ini sudah menunjukkan bahwa sudah mencapai indikator yang diharapkan yaitu $80 \%$. 
Respon siswa sekolah dasar pada waktu mengikuti kegiatan belajar mengajar dengan menggunakan media kartu jodoh adalah sebagai berikut: (1) Pada aspek 1, $100 \%$ atau 37 siswa merasa senang pada saat berlangsungnya proses pembelajaran dengan menggunakan media kartu jodoh. (2) Pada aspek 2, 100\% atau 37 siswa menyatakan bahwa pembelajaran dengan menggunakan media kartu jodoh lebih baik dari pada tidak menggunakan media seperti pembelajaran sebelumnya.(3) Pada aspek 3, 100\% atau 37 siswa tertarik dengan media kartu jodoh yang diberikan oleh guru. (4) Pada aspek 4, 94,6\% atau 35 siswa dalam pembelajaran menggunakan media kartu jodohmereka lebih memahami materi yang diajarkan oleh ibu guru. (5) Pada aspek 5, 100\% atau 37 siswa bersemangat belajar jika pembelajaran tematik menggunakan media kartu jodoh. (6) Pada aspek 6, 100\% atau 37 siswa menyatakan bahwa perhatian mereka lebih meningkat saat pembelajaran tematik dilakukan dengan menggunakan media kartu jodoh. (7) Pada aspek 7, 100\% atau 37 siswa menyatakan bahwa media kartu jodoh ini cocok digunakan dalam pembelajaran tematik ini

\section{PENUTUP}

Berdasarkan hasil pengolahan data dan pembahasan hasil penelitian ini, maka dapat ditarik kesimpulansebagai berikut: (1) Proses pelaksanaan pembelajaran oleh guru dengan menggunakan media kartu jodoh sangat baik diterapkan untuk siswa. Hal ini ditunjukkan dengan adanya peningkatan aktivitas guru dalam proses pelaksanaan pembelajaran pada siklus I pertemuan 1 aktivitas guru mencapai $75 \%$ mengalami peningkatan menjadi $77,3 \%$ pada siklus I pertemuan 2. Pada siklus II pertemuan 1 aktivitas guru mencapai $85 \%$ mengalami peningkatan menjadi $92,9 \%$ pada siklus II pertemuan 2. (2) Aktivitas siswa selama pembelajaran dengan menggunakan media kartu jodoh pada siklus I pertemuan 1 sebesar 73,4\% mengalami peningkatan pada siklus I pertemuan 2 menjadi 77,7\%. Pada siklus II pertemuan 1 sebesar 87,5\% mengalami peningkatan pada siklus II pertemuan 2 menjadi 91,6\%. (3) Hasil belajar siswa kelas III pada pembelajaran tematik dari siklus I sebesar 69,8\% meningkat pada siklus II sebesar 
87,5\%. Hal ini membuktikan bahwa dengan memanfaatkan media kartu jodoh dalam proses pembelajaran dapat meningkatkan hasil belajar siswapada siklus I dan siklus II.

\section{DAFTAR PUSTAKA}

Arsyad,Azhar.2009.Media Pembelajaran.Jakarta:PT Raja Grafindo Persada.

Arikunto. 2006. Penelitian Tindakan Kelas. Jakarta:PT Raja Grafindo Persada.

Jihat,Asep, dkk.2010.Evaluasi Pembelajaran.Yogyakarta:Multi Pressindo.

Sadiman,Arief dkk.2010.Media Pendidikan Pengertian, Pengembangan, \& Pemanfaatannya.Jakarta:PT Raja Grafindo Persada.

Sudjana,Nana dkk.2010.Media Pembelajaran.Bandung:Sinar Baru Algensindo.

Sudjana,Nana.2011.Dasar-Dasar Proses Belajar Mengajar.Bandung:Sinar Baru Algensindo.

Trianto. 2007. Model Pembelajaran Terpadu dalam Teori dan Praktek. Jakarta: Prestasi Pustaka.

Trianto.2010.Mengembangkan Model Pembelajaran Tematik.Jakarta:PT Prestasi Pustakaraya.

Wahyudin, Dinn. Dkk. 2008. Pengantar Pendidikan. Jakarta: Universitas Terbuka 